\title{
Cyanotic nephropathy and use of non-ionic contrast agents during cardiac catherization in patients with cyanotic congenital heart disease
}

\author{
Sven Dittrich, Katrin Kurschat, Ingo Dähnert, Michael Vogel, Christian Müller, ${ }^{*}$ Peter E. Lange \\ Deutsches Herzzentrum Berlin and ${ }^{*}$ Departement of Clinical Chemistry and Biochemistry, Charité, Campus Virchow - Clinics, \\ Humboldt University, Berlin, Germany
}

\begin{abstract}
Background: Chronic cyanosis with its associated rheologic changes is a known risk factor for glomerular nephropathy. Therefore, contrast-induced nephrotoxicity should be an important consideration for angiographers comparable to diabetics. On the other hand, progressions in diagnostic and interventional techniques have led to expanded indications and a more widespread use of $\mathrm{x}$-ray contrast agents. The aim of this study was to investigate the risk of contrast-induced nephropathy in the small group of patients with cyanotic heart disease prior to surgical repair. Methods: We investigated 23 cyanotic patients with an oxygen saturation of $82(50-92) \%$, age 25 (5-63) years, and 13 control subjects with atrial septal defect, age 37 (20-66) years. Blood viscosity was measured before and after cardiac catherization. Renal damage was evaluatated by selective analysis of urinary proteins and enzymes. Results: Before cardiac catheterization, $48 \%$ of the cyanotic patients had a moderate glomerulopathy. Cardiac catherization was performed with 3.0 (1.2 $6.8) \mathrm{mls} / \mathrm{kg}$ non ionic contrast medium. Only one of the 23 patients $(4.3 \%)$ with normal urinary analysis before cardiac catheterization showed renal damage, which involved tubular and glomerular function. Elevated blood viscosity in cyanotic patients was slightly reduced by the contrast. None of the acyanotic controls had contrast-induced nephropathy. Conclusions: The use of non-ionic contrast medium does not worsen cyanotic glomerulopathy. This finding may be due to the reduction of blood viscosity by the application of the contrast medium. The finding of contrast-induced nephropathy in one patient underlines the importance of monitoring renal function after cardiac catheterization.
\end{abstract}

Keywords: cardiac catheterization, cyanotic congenital heart disease, renal fallure, blood viscosity, contrast-induced nephrotoxicity

$\mathrm{N}$ EPHROPATHY HAS LONG BEEN RECOGNIZED as a potential complication of chronic cyanotic congenital heart disease. ${ }^{1}$ Recent studies with a selective and discriminating urinary analysis have revealed glomerular lesions to be the prominent feature of renal disease, although there may be a mild accompanying tubular dysfunction. ${ }^{2-4}$ An increased hematocrit was postulated to be involved in the pathogenesis of the renal damage in chronic cyanotic patients. ${ }^{2-3}$

Correspondence to. Dr. Sven Dittrich, Deutsches Herzzentrum Berlin, Abteilung Angeborene Herzfehler/Kinderkardıologie, Augustenburger Platz 1, Berlin, Germany. Tel: +49-30-4593-2800; Fax +49-30-4593-2900; E-mail: svsdittr@aol.com
Contrast-induced nephrotoxicity is a common concern among angiographers in groups of patients like diabetics, who are known to be at increased risk. The causes of contrast-induced nephrotoxicity are not well understood. The identification and preparation of patients at risk are important. ${ }^{5}$

On the other hand, progression in diagnostic and interventional techniques has led to expanded indications and a more widespread use of $x$-ray contrast agents. Because of this, we investigated the risk of contrast-induced nephropathy in the small group of patients with cyanotic congenital heart disease prior to surgical repair. 


\section{Patients and methods}

\section{Patient selection}

We studied 23 consecutive patients with cyanotic congenital heart disease older than 5 years of age, who presented to our hospital for cardiac catheterization between May 1998 to March 1999. Patients with congenital renal abnormalities $(n=1)$, a history of endocarditis $(n=1)$ or diabetes $(n=2)$ were excluded from the investigation. The control group comprised 13 acyanotic patients with atrial septal defect (Table 1). The study protocol was approved by the Ethics Committee of the Humboldt University, Berlin. Patients, and parents of patients younger than 18 years, gave informed consent to participate in this study.

\section{Evaluation of renal function}

Renal function was evaluated by analysis of proteins and enzymes analysis in spontaneously voided samples of urine taken before and 24 hours after cardiac catheterization. Protein- and albuminuria, as well as the appearance of the high molecular proteins transferrin and immunoglobuline $G$ in the urine, gave evidence for glomerular lesions. Presence of $\alpha_{1}$-microglobulinuria, and increased activity of the $\mathrm{N}$-acteyl- $\beta$-D-glucosaminidase, indicated tubular damage. Serum creatinine and urea were analyzed by a Hitachi $917^{\circledR}$-analyzer with commercial test kits (Boehringer, Mannheim,
Germany). Urinary total protein, albumin, $\alpha_{1}-$ microglobulin, transferrin, immunoglobuline $G$ and the activity of the N-acteyl- $\beta-\mathrm{D}$ glucosaminidase were analyzed and expressed as ratios relative to creatinine as previously described. ${ }^{2}$

\section{Cardiac catheterization}

Cardiac catherization was performed after overnight fasting. If the procedure did not take place in the early morning, patients recieved 500 or $1000 \mathrm{mls}$ of intravenous isotonic electrolyte solution prior to the investigation. Angiography was performed using the monomeric non-ionic contrast medium iopromide (Ultravist $370^{\circledR}$, Schering, Berlin, Germany).

\section{Probe schedule}

A first blood sample, and a specimen of urine, were taken after the overnight fasting prior to cardiac catheterization. A second blood sample was taken at the end of the investigation. A second urine sample was taken 24 hours after the end of catheterization.

\section{Evaluation of blood rbeology}

Hematocrit, hemoglobin and red cell index were measured using a Coulter counter model Celldyn $3500^{\circledR}$ (Abbott, Illinois, USA). Viscosity was

Table 1. Urine analysis in cyanotic heart disease and ASD-controls before cardiac catherization

\begin{tabular}{|c|c|c|c|}
\hline value & $\begin{array}{l}\text { Cyanotic heart disease } \\
n=23 \\
\text { No. of patients with } \\
\text { pathological analyzis } \\
\text { range (mg } \mathrm{g}^{-1} \text { crea) }\end{array}$ & $\begin{array}{l}\text { ASD controls } \\
\mathrm{n}=13 \\
\text { No. of patients with } \\
\text { pathological analyzis } \\
\text { range (mg } \mathrm{g}^{-1} \text { crea) }\end{array}$ & $\mathbf{p}-$ \\
\hline $\begin{array}{l}\text { Total protein } \\
\left(>150 \mathrm{mg} \mathrm{g}^{-1} \text { crea counted }\right. \\
\text { as pathological) }\end{array}$ & $\begin{array}{l}8 \\
(229-3327)\end{array}$ & $\begin{array}{l}1 \\
(4220)\end{array}$ & 0.0009 \\
\hline $\begin{array}{l}\text { Albumin } \\
\text { (> } 35 \mathrm{mg} \mathrm{g}^{-1} \mathrm{crea} \text { counted } \\
\text { as pathological) }\end{array}$ & $\begin{array}{l}11 \\
(41-2829)\end{array}$ & $\begin{array}{l}1 \\
(2232)\end{array}$ & 0.043 \\
\hline $\begin{array}{l}\text { [alpha }]_{1} \text {-microglobulin } \\
\text { ( }>16 \mathrm{mg} \mathrm{g}^{-1} \text { crea } \\
\text { counted as pathological) }\end{array}$ & $\begin{array}{l}3 \\
(24.2-267.3)\end{array}$ & $\begin{array}{l}1 \\
(18.2)\end{array}$ & n.s. \\
\hline $\begin{array}{l}\text { Transferrin } \\
\left(>0 \mathrm{mg} \mathrm{g}^{-1} \text { crea }\right. \\
\text { counted as pathological) }\end{array}$ & $\begin{array}{l}10 \\
(0.8-242)\end{array}$ & $\begin{array}{l}1 \\
(180)\end{array}$ & 0.021 \\
\hline $\begin{array}{l}\text { Immunglobulin } G \\
\text { ( }>0 \mathrm{mg} \mathrm{g}^{-1} \text { crea } \\
\text { counted as pathological) }\end{array}$ & $\begin{array}{l}7 \\
(1.3-171)\end{array}$ & $\begin{array}{l}1 \\
(42)\end{array}$ & 0.034 \\
\hline $\begin{array}{l}\text { N-acteyl-á-D- } \\
\text { glucosaminidase } \\
\text { (> } 11 \mathrm{U} \mathrm{g}^{-1} \text { crea } \\
\text { counted as pathological) }\end{array}$ & $\begin{array}{l}2 \\
(15.7-18.3)\end{array}$ & 0 & 0.04 \\
\hline
\end{tabular}


measured using a cone and plate viscosimeter (Wells-Brookfield, Massachusetts, USA) at shear rates of $11.3 \mathrm{~s}^{-1}$ and $230 \mathrm{~s}^{-1}$ at a temperature of $37^{\circ} \mathrm{C}$. Blood samples were anticoagulated with dipotassium EDTA, kept at $8{ }^{\circ} \mathrm{C}$, and measured within 5 hours. Viscosity was measured after equilibration with a mineral oil standard (WellsBrookfield, Massachusetts, USA) on $0.5 \mathrm{ml}$ samples of either whole blood, or plasma obtained after centrifugation for $10 \mathrm{~min}$ at $3000 \mathrm{~g}$.

\section{Analysis of data}

Statistical analysis was performed using the MannWhitney-U-test for unpaired samples and Spearman correlation coefficients with the statistical package of social analyses.

\section{Results}

The diagnoses of the 23 cyanotic patients are listed in Table 2. Seven of them had previoulsy undergone cardiac surgery, either construction of aortopulmonary shunts or corrective surgery leaving residual defects, which had been performed with cardiopulmonary bypass in 6 cases.

Before catheterization, the serum creatinine was $0.83(0.51-1.31) \mathrm{mg} / \mathrm{dl}$ in the cyanotic and $0.91(0.78-1.45) \mathrm{mg} / \mathrm{dl}$ in the acyanotic groups (n.s.). Serum urea was $31(18-48) \mathrm{mg} / \mathrm{dl}$ versus 25 $(20-35) \mathrm{mg} / \mathrm{dl}(\mathrm{p}=0.048)$. In the cyanotic group, 11 of the $23(48 \%)$ patients had increased albuminuria ( $>35 \mathrm{mg} \mathrm{g}^{-1} \mathrm{crea}$ ), 8 (35\%) of them with elevated concentration of urinary protein $(>150$ $\left.\mathrm{mg} \mathrm{g}^{-1} \mathrm{crea}\right)$. In 3 patients $(13 \%)$ there was elevation in the concentration of urinary $\alpha_{1}$ microglobulin (> $\left.16 \mathrm{mg} \mathrm{g}^{-1} \mathrm{crea}\right)$, and $2(8.7 \%)$

Table 2. Diagnoses of patients with cyanotic congenital heart disease

\begin{tabular}{ll}
\hline Dianoses & Patient numbers \\
\hline $\begin{array}{l}\text { Tètralogy of Fallot or } \\
\text { Double outlet right ventricle with } \\
\text { pulmonary stenosis }\end{array}$ & 8 \\
$\begin{array}{l}\text { Tetralogy of Fallot with pulmonary atresia } \\
\text { Complete transposition with VSD and }\end{array}$ & 4 \\
pulmonary stenosis & 2 \\
$\begin{array}{l}\text { VSD or patent arterial duct with } \\
\text { Eisenmenger syndrome }\end{array}$ & \\
$\begin{array}{l}\text { Double inlet left ventricle with discordant } \\
\text { ventriculo-arterial connection and }\end{array}$ & 3 \\
pulmonary stenosis & \\
$\begin{array}{l}\text { Congenitally corrected transposition with } \\
\text { VSD and pulmonary stenosis }\end{array}$ & 2 \\
$\begin{array}{l}\text { Tricuspid atresia with restrictive VSD } \\
\text { Ebstein's malformation with ASD }\end{array}$ & 2 \\
\hline
\end{tabular}

VSD - ventricular septal defect; ASD - atrial septal defect patients had elevated urinary activity for $\mathrm{N}$ acteyl- $\beta$-D-glucosaminidase $\left(>11 \mathrm{U} \mathrm{g}^{-1}\right.$ crea) (Table 1). In the cyanotic patients, the hematocrit, blood and plasma viscosity were all elevated, and mean corpuscular volume and mean corpuscular hemoglobin were decreased compared to acyanotic controls (Table 3). In the cyanotic patients, blood but not plasma viscosity was correlated to hemoglobin, hematocrit and oxygen saturation (Table 4). No correlation was found between age, oxygen saturation, blood- and rheology parameters to the parameters for the urine. In the control group, only one ( $8 \%$ ) patient had a pathologic albuminuria and elevated urinary total protein concentration (Table 1). In all other acyanotic patients, analysis of urine prior to catherization was normal.

The amount of contrast medium was 3.0 (1.2$6.8) \mathrm{mls} / \mathrm{kg}$ in the cyanotic and $0.73(0.5-2.7)$ $\mathrm{mls} / \mathrm{kg}$ in the control group ( $\mathrm{p}<0.01$ ). After cardiac catheterization, the viscosity of whole blood viscosity decreased in 14 of the 23 cyanotic patients from mean 17.2 to 12.9 CPS ( $p>0.05$ ) (Fig. 1). Plasma viscosity increased in 13 from 23 cyanotic patients from mean 3.47 to 6.75 CPS $(\mathrm{p}=$ n.s.) (Fig. 2). Urinary albumin concentration decreased in 2 cyanotic patients with pathological measurements before cardiac catheterization (Fig. 3). The patient with the highest concentration of albumin in the urine was the one with the highest whole-blood viscosity (Fig. 1). The concentration of albumin in the urine increased in 1 cyanotic patient, whose analyses had been non-pathological prior to cardiac catherization, to pathologic values after cardiac catherization (Fig. 3). This increase of urinary albumin in this particular patient was associated with an increase in urinary $\mathrm{N}$-acteyl$\beta$-D-glucosaminidase to highly pathologic levels (Fig. 4). In this patient who was aged 13 years and had the diagnosis of tetralogy of Fallot, with an oxygen saturation of $81 \%$, and hematocrit of $63 \%$, the exposure to contrast was $4.2 \mathrm{mls} / \mathrm{kg}$. In the other cyanotic patients, urinary $\mathrm{N}$-acteyl $-\beta$ $D$-glucosaminidase was slightly elevated in 2 cases, staying at the same level prior to and after catheterization (Fig. 4). In the control group, none of the patients developed pathological features of urinary analyzis (Figs 3,4 ).

\section{Discussion}

Our data show that the use of non-ionic monomer contrast agent is rarely detrimental to renal function in patients with cyanotic congenital heart 
Table 3. Viscosity measurements in cyanotic heart disease and ASD-controls before cardiac catheterization

\begin{tabular}{|c|c|c|c|}
\hline value & $\begin{array}{l}\text { Cyanotic heart disease } \\
\mathbf{n}=23 \\
\text { median (range) }\end{array}$ & $\begin{array}{l}\text { ASD controls } \\
\mathrm{n}=13 \\
\text { median (range) }\end{array}$ & p- \\
\hline Oxygen saturation (\%) & $\begin{array}{l}82 \\
(50-92)\end{array}$ & $\begin{array}{l}99 \\
(90-100)\end{array}$ & 0.0001 \\
\hline $\begin{array}{l}\text { Whole-blood viscosity } \\
11.3 \mathrm{~s}^{-1} \text { (CPS) }\end{array}$ & $\begin{array}{l}12.9 \\
(6.31-28.2\end{array}$ & $\begin{array}{l}8.42 \\
(6.58-11.4)\end{array}$ & 0.001 \\
\hline $\begin{array}{l}\text { Whole-blood viscosity } \\
225 \mathrm{~s}^{-1} \text { (CPS) }\end{array}$ & $\begin{array}{l}5.4 \\
(3,37-9,95)\end{array}$ & $\begin{array}{l}4.44 \\
(3,77-5,44)\end{array}$ & 0.004 \\
\hline $\begin{array}{l}\text { Plasma viscosity } \\
11.3 \mathrm{~s}^{-1} \text { (CPS) }\end{array}$ & $\begin{array}{l}2.87 \\
(2.25-7.95)\end{array}$ & $\begin{array}{l}2.04 \\
(1.84-4.09)\end{array}$ & 0.004 \\
\hline $\begin{array}{l}\text { Plasma viscosity } \\
225 \mathrm{~s}^{-1} \text { (CPS) }\end{array}$ & $\begin{array}{l}1.59 \\
(1.24-2.5)\end{array}$ & $\begin{array}{l}1.49 \\
(1.29-1.63)\end{array}$ & n.s. \\
\hline Hematocrit (\%) & $\begin{array}{l}53.8 \\
(37.8-75.2)\end{array}$ & $\begin{array}{l}43.1 \\
(37.6-51)\end{array}$ & 0.002 \\
\hline $\operatorname{MCV}(\mathrm{fl})$ & $\begin{array}{l}87 \\
(67.7-96.8)\end{array}$ & $\begin{array}{l}91.3 \\
(85.9-98.5)\end{array}$ & 0.014 \\
\hline $\mathrm{MCH}(\mathrm{pg})$ & $\begin{array}{l}28.8 \\
(20.3-32.7)\end{array}$ & $\begin{array}{l}30.7 \\
(27.8-34)\end{array}$ & 0.007 \\
\hline $\mathrm{MCHC}(\mathrm{g} / \mathrm{dl})$ & $\begin{array}{l}33.2 \\
(29.4-35.2)\end{array}$ & $\begin{array}{l}33.7 \\
(32.3-34.6)\end{array}$ & 0.035 \\
\hline
\end{tabular}

CPS - Centipoise; MCV - mean corpuscular volume; MCH - mean corpuscular hemoglobin; MCHC - mean corpuscular hematocrit

Table 4. Correlation between hematocrit and oxygen saturation to blood viscosity in cyanotic patients

\begin{tabular}{lll}
\hline & $\begin{array}{l}\text { Blood viscosity (CPS) } \\
\text { (shear rate 225 } \mathrm{s}-1)\end{array}$ & $\begin{array}{l}\text { Blood viscosity (CPS) } \\
\text { (shear rate 11.3 s-1) }\end{array}$ \\
\hline Hemoglobin (g/dl) & $\mathrm{r}=0.91, \mathrm{p}<0.01$ & $\mathrm{r}=0.76, \mathrm{p}<0.01$ \\
Hematocrit (\%) & $\mathrm{r}=0.95, \mathrm{p}<0.01$ & $\mathrm{r}=0.82, \mathrm{p}<0.01$ \\
Oxygen saturation (\%) & $\mathrm{r}=-0.67, \mathrm{p}<0.01$ & $\mathrm{r}=-0.75, \mathrm{p}<0.01$ \\
\hline
\end{tabular}

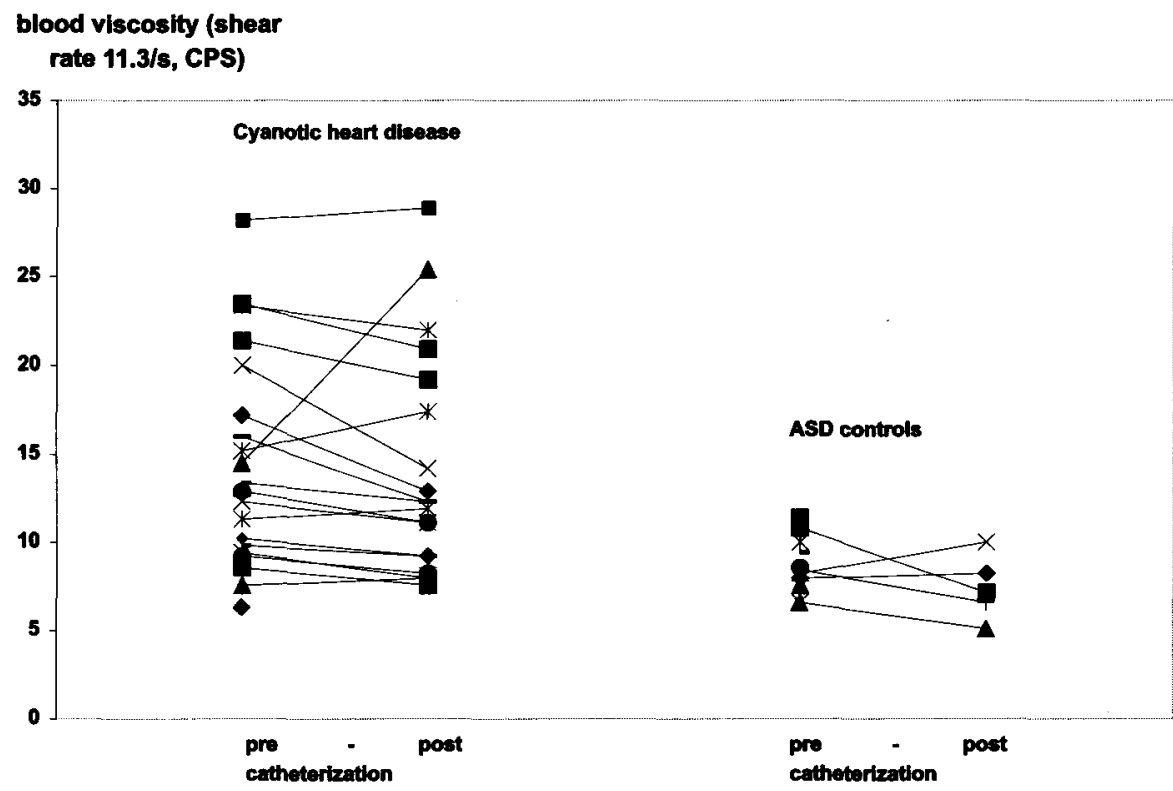

Figure 1.

Whole-blood viscosity pre and post cardiac catheterization: Blood viscosity at shear rate $11.3 \mathrm{~s}-1$, representing arteriolar flow conditions, was elevated in cyanotic patients compared to acyanotic controls $(p=0.001)$. After cardiac catheterization, blood viscosity was slightly reduced in most patients $(p<0.05)$. 


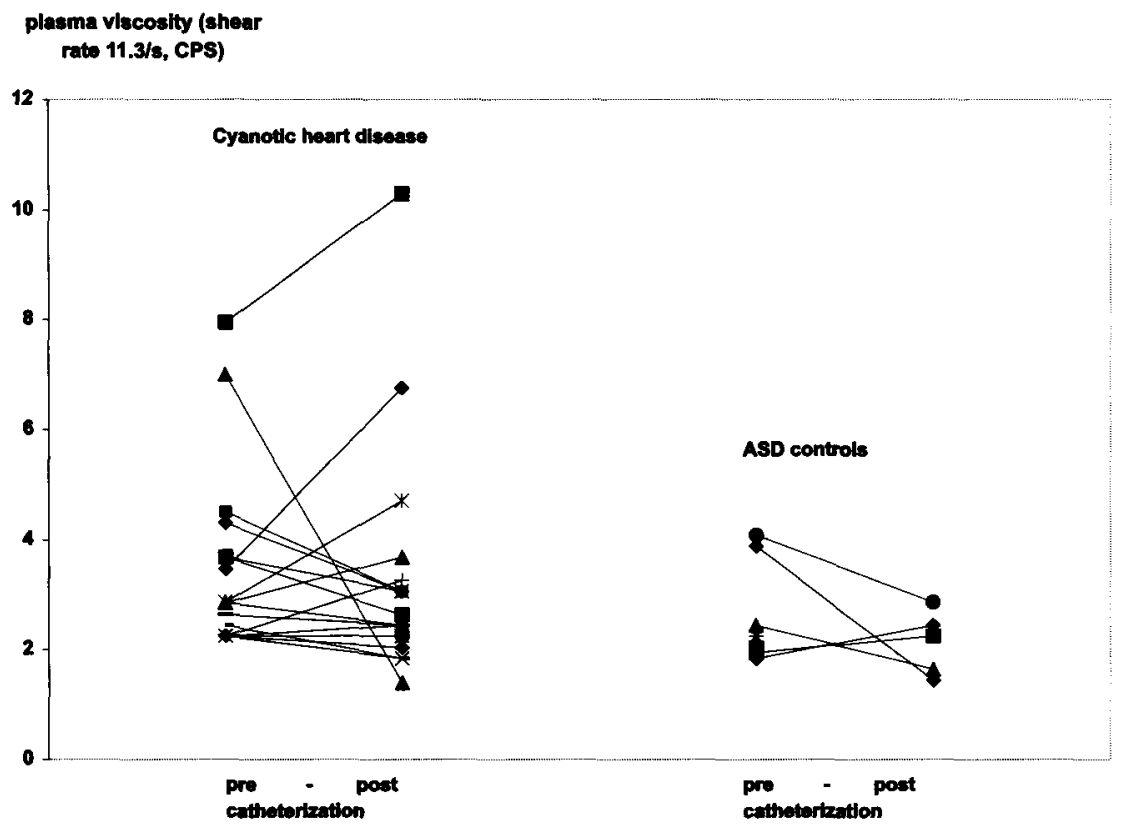

Figure 2.

Plasma viscosity pre and post cardiac catbeterization: Plasma viscosity at sbear rate $11.3 \mathrm{~s}^{-1}$, representing arteriolar flow conditions, was slightly elevated in cyanotic patients compared to acyanotic controls $(p=0.004)$. After cardiac catheterization, plasma viscosity was changed in both directions in individual patients and did not differ significantly to pre catbeterization values.

albuminuria (mg g-1 creatinine)

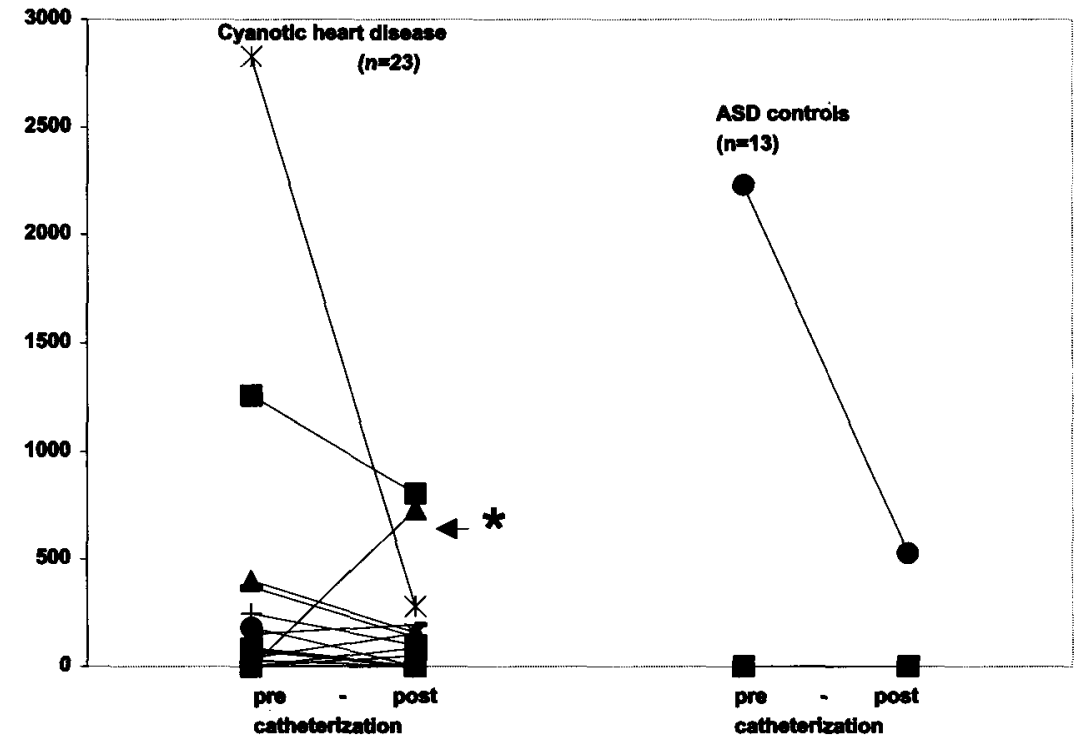

Figure 3.

Urinary albumin concentration pre and post cardiac catbeterization: Eleven patients in the cyanotic group and 1 patient in the ASD group bad a glomerulopatby with albuminuria $>35 \mathrm{mg} g-1$ creatinine before catberization $(p=0.04$ ). One cyanotic patient (asterix) with normal pre catberization analyzis developed albuminuria of $730 \mathrm{mg} \mathrm{g-1} \mathrm{creatinine,} \mathrm{associated} \mathrm{with} \mathrm{renal} \mathrm{tubular} \mathrm{damage} \mathrm{(see} \mathrm{asterix} \mathrm{in} \mathrm{Fig} \mathrm{4).}$ 
B-NAG (U g-1 creatinine)



Figure 4.

$N$-acteyl- $\beta-D$-glucosaminidase activity in the urine pre and post cardiac catheterization: Before catberization, only 2 cyanotic patients showed moderate tubular damage as indicated by sligbtly elevated $N$-acteyl- $\beta$-D-glucosaminidase ( $>11 \mathrm{Ug}-1$ creatinine), thus underlining the primary glomerular character of nephropathy in long standing cyanosis. One patient (asterix) showed contrast induced tubular damage with an increase of the $N$-acteyl- $\beta$ - $D$-glucosaminidase to $280 U \mathrm{~g}-1$ creatinine.

disease, even in those who exhibited moderate glomerular damage (Table 1). In all but one patient, no new glomerular or tubular renal damage could be found after administration of contrast (Figs 3, 4). We used non-ionic contrast agent. The advantages of non-ionic over ionic monomer contrast agents with regards to chemotoxicity and osmotoxicity have been demonstrated before in a number of studies. ${ }^{6-12}$ Although the evidence is inconclusive, radiocontrast-induced nephropathy has been shown to result from an ischemic injury to the medullary portion of the kidney secondary to intense renal vasoconstriction. ${ }^{13,14}$ The low risk found in our patients may be due to a positive effect of the contrast agent on blood viscosity (Fig. 1) which, in turn, improves the properties of arteriolar flow in this special group of patients with erythrocytosis. ${ }^{2,3,15}$ The medullary portion of the kidney is provided by a second capillary bed, which is in series after the glomerular capillaries. To maintain normal blood flow in the peritubular capillaries though the increased resistance to flow of viscous blood in patients with elevated hematocrit, a higher intravascular pressure is required, which results in proteinuria (Table 1). ${ }^{16}$ Previous important impairment of renal function has been found to be a risk factor for renal damage by contrast media., ${ }^{5,17-19}$ But, in chronic cyanotic heart disease, only moderate glomerular lesions and only a mild accompanying tubular dysfunction (Table 1) ${ }^{2-4}$ are the prominent features of renal impairment. ${ }^{2,3}$ Thus, our results confirm the reported low risk in the use of non-ionic contrast agents. ${ }^{20}$ In turn, the relatively low irritability of cyanotic patients to radiocontrast induced medullary hypoxia provides further evidence for the glomerular character of cyanotic nephropathy.

Moderate tubular damage appearing in one patient without cyanotic glomerulopathy shows that there is a small, but definite, risk for radiocontrastinduced nephropathy even in patients at low risk who are undergoing elective cardiac catheterization. This can be detected only when very sensitive laboratory tests are employed. ${ }^{20}$ Our procedure of intravenous fluid substitution if fasting took more than 8 hours may have helped to keep the incidence of radiocontrast-induced nephropathy low, as careful hydration and production of a high flow of urine have been shown the only prooven method to minimize the incidence of radiocontrast-induced nephropathy in patients known to be at risk. $13,21,22$ 


\section{Limitations of this study}

In this retrospective analyis, the amount of the contrast agent used in the control patients was lower, which may have influenced the findings, as changes in rheology or renal function can be influenced by the degree of cyanosis or the dose of contrast agent.$^{23-25}$ Since we did not find a significant increase in renal impairment in our patients, and essentially report a negative effect, the lower dose of contrast is unlikely to have influenced our data.

\section{Conclusions}

From our data, we conclude that it is advisable to monitor renal function in patients with cyanotic congenital heart disease who undergo cardiac catheterization, but note that use of non-ionic monomer contrast agents does not generally lead to further impairment of renal function in patients with cyanotic glomerulopathy. Good hydration may help to keep low the risk of radiocontrastinduced nephropathy.

\section{References}

1. Spear $\mathrm{G}$. The glomerulus in cyanotic congenital heart disease and primary pulmonary hypertension. Nephron 1964;1:238-248.

2. Dittrich S, Haas NA, Bührer C, Müller C, Dähnert I, Lange PE. Renal impairment in patients with long-standing cyanotic congenital heart disease. Acta Paediatr 1998;87:949-954.

3. Krull F, Ehrich JH, Wurster U, Toel U, Rothganger S, Luhmer I. Renal involvement in patients with congenital cyanotic heart disease. Acta Paediatr Scand 1991;80:1214-1219.

4. Akita H, Matsuoka S, Kuroda Y. Nephropathy in patients with cyanotic congenital heart disease. Tokushima J Exp Med 1993;40:47-53.

5. Tommaso CL. Contrast-induced nephrotoxicity in patients undergoing cardiac catheterization. Cathet Cardiovasc Diagn 1994;31:316-321.

6. Carraro M, Malalan F, Antonione R, Stacul F, Cova M, Petz S, Assante M, Grynne B, Haider T, Palma LD, Faccini L. Effects of a dimeric vs a monomeric nonionic contrast medium on renal function in patients with mild to moderate renal insufficiency: a double-blind, randomized clinical trial. Eur Radiol 1998;8:144-147.

7. Barrett BJ, Carlisle EJ. Metaanalysis of the relative nephrotoxicity of high- and low-osmolality iodinated contrast media. Radiology 1993;188:171-178.

8. Spinler SA, Goldfarb S. Nephrotoxicity of contrast media following cardiac angiography: pathogenesis, clinical course, and preventive measures, including the role of low-osmolality contrast media. Ann Pharmacother 1992;26:56-64.
9. Stacul F, Cova M, Assante M, Hougens Grynne B, Haider T. Comparison between the efficacy of dimeric and monomeric non-ionic contrast media (iodixanol vs iopromide) in urography in patients with mild to moderate renal insufficiency. $\mathrm{Br} \mathbf{J}$ Radiol 1998;71:918-922.

10. Rudnick MR, Goldfarb S, Wexler L, Ludbrook PA, Murphy MJ, Halpern EF, Hill JA, Winniford M, Cohen MB, VanFossen DB. Nephrotoxicity of ionic and nonionic contrast media in 1196 patients: a randomized trial. The Iohexol Cooperative Study. Kidney Int 1995;47:254-261.

11. Schwab SJ, Hlatky MA, Pieper KS, Davidson CJ, Morris KG, Skelton TN, Bashore TM. Contrast nephrotoxicity: a randomized controlled trial of a nonionic and an ionic radiographic contrast agent. N Engl J Med 1989;320:149-153.

12. Almen $\mathbf{T}$. The etiology of contrast medium reactions. Invest Radiol 1994;29 Suppl 1:S37-45.

13. Solomon R. Radiocontrast-induced nephropathy. Semin Nephrol 1998;18:551-557.

14. Weisberg LS, Kurnik PB, Kurnik BR. Radiocontrast-induced nephropathy in humans: role of renal vasoconstriction. Kidney Int 1992;41:1408-1415.

15. Simpson LO. A hypothesis proposing increased blood viscosity as a cause of protennuria and increased vascular permeability. Nephron 1982;31:89-93.

16. Simpson LO. Blood viscosity induced proteinuria. Nephron 1984;36:280-281.

17. Laranja SM, Ajzen H, Schor N. Nephrotoxicity of low-osmolality contrast media. Ren Fail 1997;19:307-314.

18. Rudnick MR, Berns JS, Cohen RM, Goldfarb S. Contrast mediaassociated nephrotoxicity. Semin Nephrol 1997;17:15-26.

19. Parfrey PS, Barrett BJ. High-osmolality and low-osmolality contrast agents. N Engl J Med 1992;327:204-205.

20. Nunez BD, Allon M. Effect of cardiac catheterization on renal function. Clin Nephrol 1990;34:263-266.

21. Stevens MA, McCullough PA, Tobin KJ, Speck JP, Westveer DC, Guido-Allen DA, Timmis GC, OòÀNeill WW. A prospective randomized trial of prevention measures in patients at high risk for contrast nephropathy: results of the P.R.I.N.C.E. Study. Prevention of Radiocontrast Induced Nephropathy Clinical Evaluation. J Am Coll Cardiol 1999;33:403-411.

22. Solomon R, Werner C, Mann D, D'Elia J, Silva P. Effects of saline, mannitol, and furosemide to prevent acute decreases in renal function induced by radiocontrast agents. $\mathrm{N}$ Engl J Med 1994:331:1416-1420.

23. Cigarroa RG, Lange RA, Williams RH, Hillis LD. Dosing of contrast material to prevent contrast nephropathy in patients with renal disease. Am J Med 1989;86:649-652.

24. Lautin EM, Freeman NJ, Schoenfeld AH, Bakal CW, Haramati N, Friedman AC, Lautin JL, Braha S, Kadish EG, Haramiti N. Radiocontrast-associated renal dysfunction: a comparison of lower- osmolality and conventional high-osmolality contrast media. AJR Am J Roentgenol 1991;157:59-65.

25. Leonardi $M$. Contrast medium dose and renal fallure. Radiology 1998;207:832-833. 